\title{
スマートフィルムセンサ・アクチュエータを用いた平板構造物の モード制御に関する研究*
}

\author{
米山 聡*1, 田中信 雄*2, 岩本宏 之*1 \\ Modal Control of a Planar Structure \\ Using Smart Film Sensors and Actuators
}

\author{
Satoshi YONEYAMA*3, Nobuo TANAKA and Hiroyuki IWAMOTO \\ ${ }^{*}$ Department of Aerospace Engineering, Tokyo Metropolitan University, \\ 6-6 Asahigaoka, Hiso-shi, Tokyo, 191-0065 Japan
}

\begin{abstract}
This paper deals with modal control of one-dimensional planar structures using both distributed-parameter film sensors and actuators with a view to extracting as well as suppressing the designated structural vibration mode. First the fundamental properties of a modal control system based upon distributed-parameter sensors and actuators are discussed. It is shown that the utilization of distributed-parameter sensors and actuators leads to the elimination of spillover destabilization. A photo-resist technique on electrode patterning of a PVDF film and a laminating technique are then introduced, hence termed a multi-layer PVDF film. The use of the multi-layer PVDF film per se is found to possess the potential of modal control. Furthermore, a multi-layer PVDF filmbased one-dimensional planar structure is developed, which has the attribute of modal control. The experiment is finally conducted, demonstrating the capability of modal control for suppressing the structural mode of interest without causing any spillover effect on the other structural modes.
\end{abstract}

Key Words : Flexible Structure, Sensor, Smart Materia1, Smart Structure, Vibration Control

\section{1. 緒}

能動振動制御を支えているモ一ド制御は，対象構造 物の固有関数がもつ直交性を利用することにより，応 答にあずかる各固有モード成分を分離し，各モードに 単一フィードバック系を構築することで各モードにダ ンピングを付与したり，モード制御を講ずることで所 望のモード姿態を創造する制御である.これまでにモ 一ド制御に関する多くの報告がなされているが(1) (4), 制御系構築の基礎となる振動情報採取及び励起にはポ イントセンサやポイントアクチュエータが使用されて いるといえる，そのため，振動モ一ドが無限個存在す るような分布定数系構造物を対象とする場合，少なく とも対象とする周波数領域に存在する振動モ一ド数の 数倍程度のポイントセンサ, またはロバスト性を考慮 した新たな制御系の構築が必要となる。そのため簡素 な制御系においては，デー夕の久落や観測スピルオ一

\footnotetext{
* 原稿受付 2009 年 7 月 27 日.

*1 正員, 首都大学東京大学院システムデザイン研究科 (\$191 0065 日野市旭が丘 6-6).

*2 正員, フェロー, 首都大学東京システムデザイン学部.

E-mail : yoneyama-satoshi@sd.tmu.ac.jp
}

バを引き起こし，同様にポイントアクチュエータを使 用することで制御スピルオーバが発生することは自明 である、結果として，制御系の安定性は害されるだけ でなく, 制御対象構造物は無数のセンサとアクチュエ 一夕に取り囲まれた構造物となる.これに対し，ポイ ントセンサアクチュエータが無限個集積しているも のと夕なせる分布定数系センサ/アクチュエータを導 入することで, 必要とするセンサおよびアクチュエー 夕の減少とスピルオーバ問題の回避を達成することが できる(5)ィ9).そこで筆者らは，これまでにPVDFフィ ルムを基調とした分布定数系センサアクチュエータ の設計手法に関する提案及び実験による検証を行い, 単純支持平板の特定モード検出/励起及びスピルオー バを回避した制御が可能であることを報告している(10) 〜15). しかしながら, PVDFフィルムを基調とした平板 の振動制御は, 所望の形状にシェーピングした PVDF フィルムをアルミ板等の風直な支持体に貼付する手法 であった. そのため，(1)シェーピング及び貼付け䛊差 及び面内の質量分布による性能劣化，(2)支持体の厚さ 及び㴊直性による産業上の適用範囲の制約，（3）一枚 のフィルムから切り出し可能な形状及び枚数の制約に よる材料得率の大幅な低下と大面積化の困難性, など 
のように性能面及び工業面の両面で改良すべき点が 多々あったといえる.

このような問題点を解決する手法の一つとして，筆 者らは電極パターニング手法を用いたスマートフィル ムの創生手法を提案している(16) (18). 本手法はシェ一 ピング及び剛直な基板に貼り付けることなく, 僅か数 百 $\mu \mathrm{m}$ の柔軟な薄膜フィルムそのものに，モードフィ ルタリング機能やモードアクチュエーション機能を内 蔵できる. また本フィルムはPZT を代表とするポイン トセンサ・アクチュエータと異なり, 高い柔軟性と加 工性を有していることから, 積層化等の多機能化や大 面積化を容易に達成できる.このことはセンサ機能と アクチュエータ機能など, 複数の機能を一枚のフィル ムに内蔵できることを意味している.このようなポリ マー固有の特徵を最大限に活かすことで, 柔軟性薄層 性加工性を有する, モ一ド制御フィルムが構築可能で ある. そこで本論文では一次元分布定数系センサフィ ルムおよびアクチュエータフィルムを基調とするモー ド制御系を構築し，その効果を立証することを目的己 する．まずは本論文で対象とする分布定数系センサお よびアクチュエータを使用した場合のモード制御につ いて明らかにすることからはじめる.ささらに一次元平 板状構造物を対象とし、センサフィルムとアクチュエ ータフィルムを融合した薄層フィルムを用いてフィー ドフォワード制御系を構成し，モ一ド制御効果を検証 する.このことにより，本論文で提案する極薄膜なモ 一ド制御フィルムの機能が確証できたので, 当該フィ ルムの系統的な設計法及び作製法について明示する.

\section{2. 分布定数系センサと分布定数系アクチュエータをベー スとするモード制卸}

二次元非減衰分布定数系構造物の基礎式として, 領 域 $S$ において次の偏微分方程式を考える.

$$
L[w(r, t)]+m(r) \ddot{w}(r, t)=f(r, t)
$$

ただし， $r$ は構造物の任意点における座標 $(x, y)$, $w(r, t)$ および $\ddot{w}(r, t)$ は $r$ における振動変位および加 速度, $m(r)$ は質量密度, $f(r, t)$ は分布制御力, $L$ は 自己随伴微分演算子を表す.すると, $w(r, t)$ および $f(r, t)$ はモード関数 $\varphi_{k}(r)$ 及びモ一ド倸数 $\eta_{k}(t), f_{k}(t)$ $(k=1,2,3, \cdots)$ を用いて, 以下のように記述することがで きる.

$$
w(r, t)=\sum_{k=1}^{\infty} \varphi_{k}(r) \eta_{k}(t)
$$

$$
f(r, t)=\sum_{k=1}^{\infty} m(r) \varphi_{k}(r) f_{k}(t)
$$

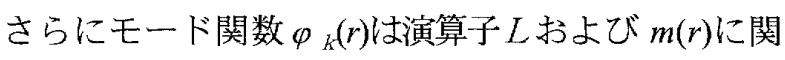
し, 正規化されているものとする.

$$
\begin{aligned}
& \int_{S} \varphi_{r}(r) L\left[\varphi_{s}(r)\right] d r=\omega_{r}{ }^{2} \delta_{r s} \\
& \int_{S} \varphi_{r}(r) m(r) \varphi_{s}(r) d r=\delta_{r s}
\end{aligned}
$$

ここで $\omega_{r}$ は $r$ 次のモード周波数， $\delta_{r s}$ はクロネッカー デル夕を表す.すると $n_{k}(t)$ および $f_{k}(t)$ は次のように記 述できる.

$$
\begin{aligned}
& \eta_{k}(t)=\int_{S} \varphi_{k}(r) m(r) w(r, t) d r \\
& f_{k}(t)=\int_{S} \varphi_{k}(r) f(r, t) d r
\end{aligned}
$$

次に分布定数系構造物を対象とし，分布定数系セン サおよび分布定数系アクチュエータで構成されるモ一 ド制御系を考える. 具体的な設定として, $s$ 次モ一ド のみに着目して，これにダンピングを付与する問題を とりあげる. すなわち, 分布定数系センサは $s$ 次の速 度モ一ド係数のみをセンシングし, 分布定数系アクチ ユエー夕は $s$ 次の振動モ一ドのみを励起する構成とす る. すると分布制御力は次のように記述できる.

$$
f(r, t)=-g_{s} m(r) \varphi_{s}(r) \dot{\eta}_{s}(t)
$$

ここで， $g_{s}$ はモード制御ゲインを表す. 次に上式を振 動方程式に代入し, この両辺に $\varphi_{i}(r)$ を乗じ, さらに領 域 $S$ にわたって積分すると

$$
\begin{aligned}
& \int_{S} \varphi_{i}(r) L\left[\sum_{k=1}^{\infty} \varphi_{k}(r) \eta_{k}(t)\right] d r \\
& +\int_{S} \varphi_{i}(r) m(r) \sum_{k=1}^{\infty} \varphi_{k}(r) \ddot{\eta}_{k}(t) d r \\
& =-g_{s} \int_{S} \varphi_{i}(r) m(r) \varphi_{s}(r) \dot{\eta}_{s}(t) d r
\end{aligned}
$$

さらに式 (4), 式 (5) に示すモードの直交性を利用す ることで上式は簡略化され，以下のようになる

$$
\ddot{\eta}_{i}(t)+g_{s} \dot{\eta}_{s}(t) \delta_{i s}+\omega_{i}{ }^{2} \eta_{i}(t)=0, \quad i=1,2,3 \cdots
$$

図 1 に分布定数系センサおよび分布定数系アクチ ユエータで構成されるモード制御系の概念図を示 す. 分布定数系構造物に発生する速度分布の中か ら, 分布定数系センサによりモード速度係数を抽 出し，つぎにこの信号をべースに制御信号が生成 され, 分布定数系アクチュエータを駆動する.こ の分布定数系アクチュエータは分布制御力 $f(r, t)$ 
を生成し，モードフィルタリングと逆の原理によ り，対象とするモードのみに制御効果を与える. また式（10）を図式化すると図 2 となる．ここで は，モード領域におけるセンシングとアクチュエ ーションの相関関係が示されており，いま対象と する $s$ 次の速度モード係数のみを抽出し, 必要な モード制御ゲインを乗じた後，当該モードのみに 制御力が印加されるので, 他のモードには一切影 響を及ぼすことはない，すなわち，観測スピルオ 一バ，制御スピルオーバを惹起することはない。

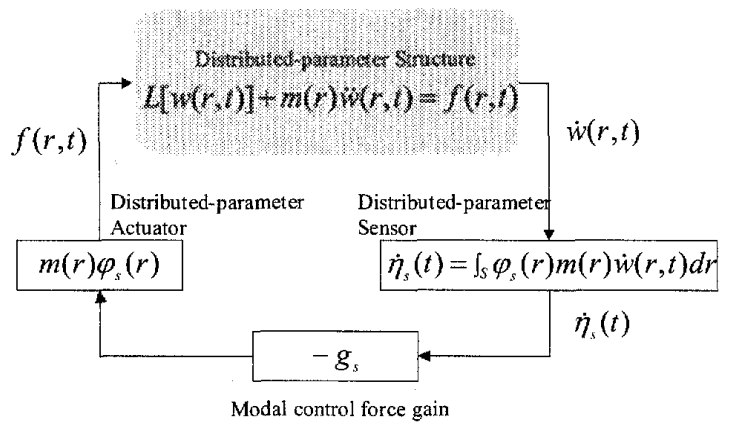

Fig. 1 Modal control system of a distributed-parameter structure with distributed-parameter sensor and actuator.

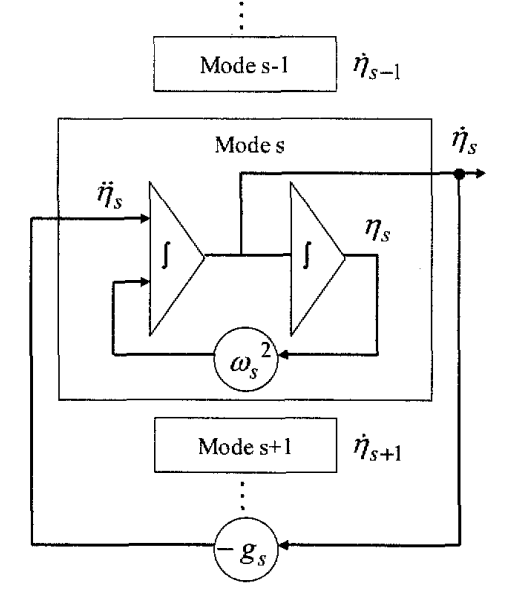

Fig. 2 Signal flow diagram of modal control using distributed parameter sensor and actuator.

\section{3. センサ・アクチュエータ給合フィルムの模築}

3・1 電極パターニングフィルム作暼手法 本論 文では, 対象とする振動モードの固有関数の 2 階微分 を形状関数とした電極パターニング PVDF フィルムを 分布定数系センサおよびアクチュエータフィルムとし て用いる.また, パターニング電極の形成手法として フォトレジスト法を採用した. アルミ電極層が両全面 に形成された総厚 $110 \mu \mathrm{m}$ の PVDF フィルム上に, $380 \mathrm{~nm}$ 以下の UV 領域の外光をカットした環境下で 2 $\mu \mathrm{m}$ のポジ型フォトレジスト層をスピンコート法によ り形成した．制御対象とする振動モードに心じて，固
有関数の 2 階微分を形状関数としたフォトマスクを用 いて，フォトレジスト層に主波長 $365 \mathrm{~nm}$ の UV 照射 $\left(0.5 \mathrm{~J} / \mathrm{cm}^{2}\right)$ を行った. 両面に同処理を施した後, アル カリ現像液を用いて露光部のフォトレジスト層ととも にアルミ電極層の除去を行った. さらにエタノールを 用いて遮光部に残存する最上層のフォトレジスト層の みを除去し，所望の電極形状を有する分布定数系セン サおよびアクチュエータフィルムを得た.

\section{3・2 センサ・アクチュエータ程居化手法 3-1} で作製した分布定数系センサフィルムとアクチュエー タフィルムを積層し，特定の振動モードを抑制可能な 積層型フィルムの作製手法を提案する. 図 3 に作製工 程の概略を示す．ポリエステルフィルムの両面にアク リル系の粘着層が叙布された粘着フィルムをアクチュ エータフィルム上にラミネータを用いて転写する (300 mm $/ \mathrm{min}$, 一往復). 続いて, もう一方の粘着面上 に $80 \mathrm{~nm}$ のアルミ層を蒝着したポリエステルフィルム を同様の手法で転写する. さらに, アルミ蒸着フィル ム上に粘着フィルムを介してセンサフィルムを転写す る. 最後に室温で 30 分放置することで, 5 層構造のセ ンサ機能とアクチュエータ機能を有する積層型フィル ムを作製する. このとき, アルミ蒸着フィルムを接地 することでセンサフィルムとアクチュエータフィルム の機能を電気的に分離する.

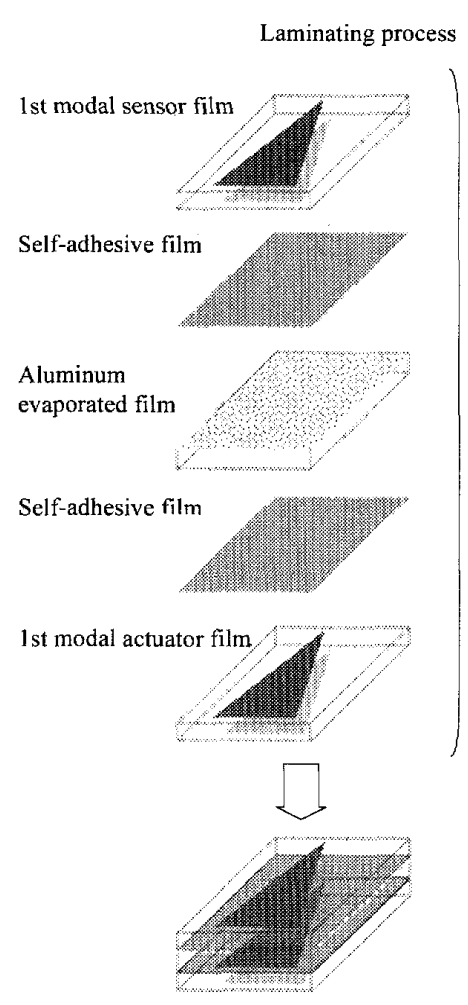

Fig. 3 Schematic diagram of fabrication process for modal control film using electrode patterning and laminating technique. 


\section{$3 \cdot 3$ フィルム特性 図4には積層フィルムの外} 観写真, 図 5 には積層後のフィルム断面の概略を示す. また対象フィルムの物性を表 1 に示す. PVDF フィル ムの厚さが $110 \mu \mathrm{m}$, 粘着フィルムの厚みは $75 \mu \mathrm{m}$, アルミ蒸着フィルムの厚みは $50 \mu \mathrm{m}$ であり, 総厚 420 $\mu \mathrm{m}$ のフィルムを作製した。本論文では制御対象とす る振動モードを 1 次モードとし, フィルムの外形を $L_{x}=4.7 \mathrm{~cm}, L_{y}=1.5 \mathrm{~cm}$, 固定一自由の一次元平板状構 造物とする. センサフィルムおよびアクチュエータフ イルムに用いた PVDF フィルムの諸特性は同一とし, 圧電応力定数 $\mathrm{e}_{31}$ は $81 \mathrm{mC} / \mathrm{m}^{2}$, 密度 $\rho$ は $1780 \mathrm{~kg} / \mathrm{m}^{3}$, ヤ ング率 $E$ は $2.5 \mathrm{Gpa}$ である.また中間層とするポリエス テルフィルムの密度 $\rho$ は $1400 \mathrm{~kg} / \mathrm{m}^{3}$, ヤング率 $E$ は 1.9Gpa である.

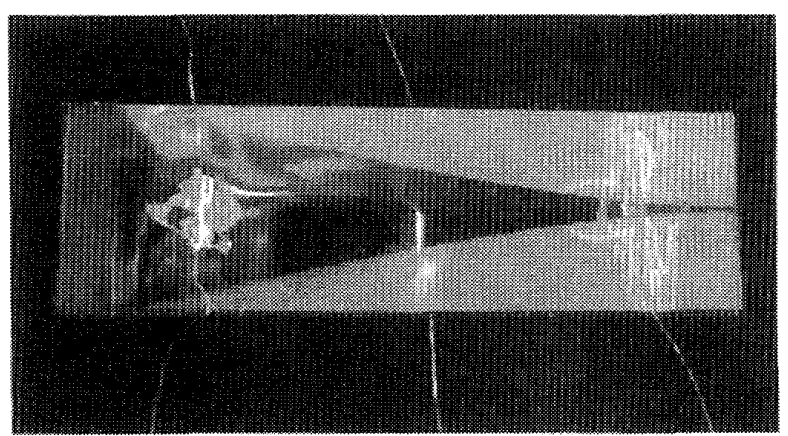

Fig. 4 Modal control film using distributed parameter sensor film and actuator. film appearance.

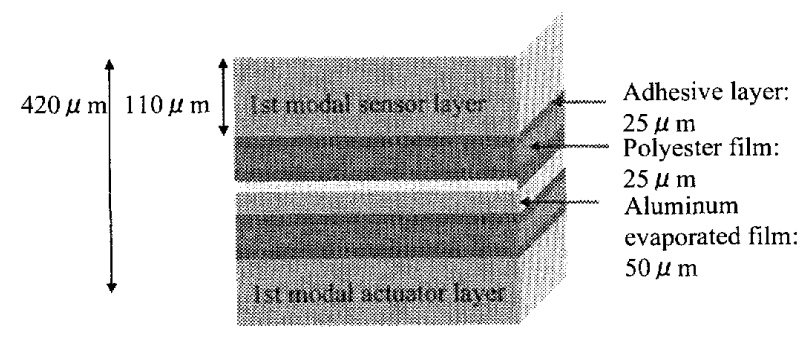

Fig. 5 Cross-section diagram of modal control film.

Table 1 Design parameters of modal control film.

\begin{tabular}{c|c|c|c|c|c|c|} 
Layer & Material & $\begin{array}{c}\mathrm{Lx} \\
{[\mathrm{cm}]}\end{array}$ & $\begin{array}{c}\mathrm{Ly} \\
{[\mathrm{cm}]}\end{array}$ & $\begin{array}{c}\mathrm{h} \\
{[\mu \mathrm{m}]}\end{array}$ & $\begin{array}{c}\text { Density } \rho \\
{\left[\mathrm{kg} / \mathrm{m}^{3}\right]}\end{array}$ & $\begin{array}{c}\mathrm{E} \\
{[\mathrm{Gpa}]}\end{array}$ \\
\hline $\begin{array}{c}\text { 1st modal } \\
\text { sensor layer }\end{array}$ & PVDF & 4.7 & 1.5 & 110 & 1780 & 2.5 \\
\hline $\begin{array}{c}\text { 1st modal } \\
\text { actuator layer }\end{array}$ & PVDF & 4.7 & 1.5 & 110 & 1780 & 2.5 \\
\hline Interlayer & Polyester & 4.7 & 1.5 & 200 & 1400 & 1.9 \\
\hline Total & - & 4.7 & 1.5 & 420 & 1599 & 2.2 \\
\hline
\end{tabular}

\section{4. モ一ド制御}

4・1 実験構成 3-1 および3-2で提案した電極パ ターニングおよび積層化手法により作製した，モード フィルタリング機能とモードアクチュエーティング機 能を内蔵した極薄膜積層フィルムからなるモ一ド制御 系を構築し，その制御効果を明らかにする，本論文で は，積層フィルムのモード制御機能を実証することに 主眼を置いているため, 制御効果が安定的に得られる フィードフォワード制御方式を適用した．また，刘象 とするフィルムが軽量かつ薄膜であることを考慮し， 加振によるロードイフェクトを避けるため, 非接触加 振である音響加振法を採用した。 また，対象フィルム の駆動点インピーダンスは, 観測点 $r=(1.30,0.75)$ にお ける速度をレーザー変位計により非接触で測定し，対 象周波数領域を $550 \mathrm{~Hz}$ までとする.

図 6 に適応フィードフォワード制御系構成図を示す. 積層フィルム中のセンサ層からチャージアンプを介し て得られる出力を誤差信号として, Filtered-X LMS ア ルゴリズムを基調とする適応フィードフォワード制御 コントローラに入力する. またこの際に使用したサン プリング周波数は $2362 \mathrm{~Hz}$, コントローラとキャンセレ ーションパスのタップ数は 256 とした. ここで誤差信 号を最小化する最適制御則を講じ，アクチュエー夕層 にパワーアンプを介して制御信号を出力する. センサ 層およびアクチュエー夕層は対象とする振動モードの み検出および励起するため, 結果として無数個励起さ れた振動モードの中から対象とする振動モードのみを 抑制する構図になる。

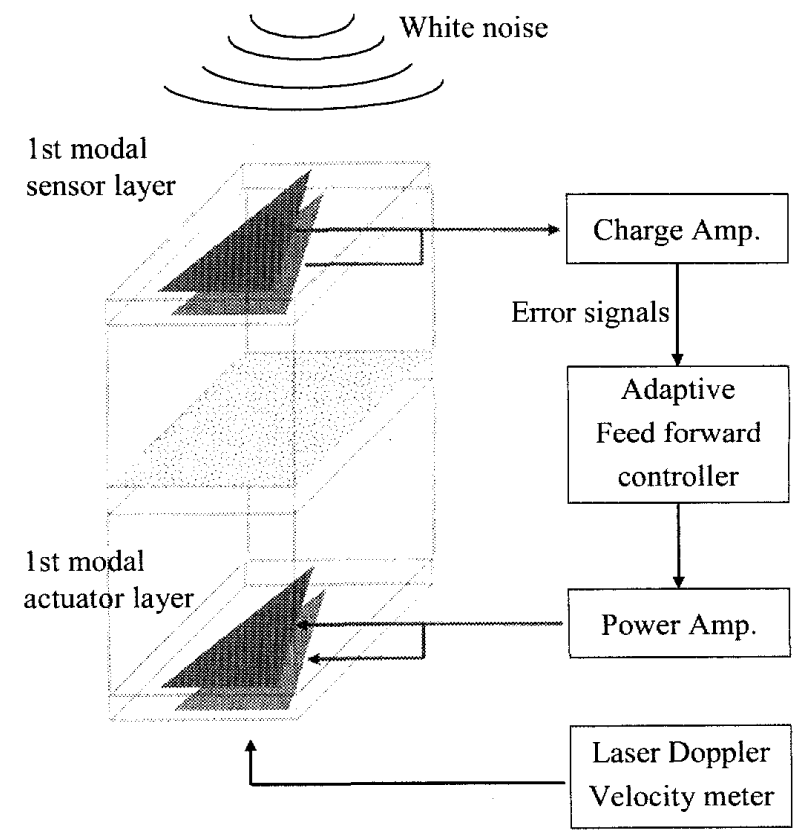

Fig. 6 Experimental set up of 1st modal control using feed forward control. 
4・2 制御効果の検証 積層型フィルム中の一次 モードセンサ層からの出力を誤差信号として，適応フ イードフォワード制御を行った. 図 7 および図 8 はレ 一ザー変位計で得た対象フィルムの振動速度周波数応 答を示しており，図 7 は非制御状態，図 8 は制御状態 を示す，図7 から，対象フィルムには $550 \mathrm{~Hz}$ 以下にお いて3つの振動モードが存在していることがわかる. 非制御状態との比較から明らかなように，1 次モード において $15 \mathrm{~dB}$ の抑制効果を得ている. また対象とす る振動モードのみが明確に抑制されていることに着目 されたい，本論文では同等の特性を有するPVDF フィ ルムをセンサ層及びアクチュエータ層として使用した が, 各層に使用する材料物性及び積層構成の最適化は, 制御効果向上手段の一つと考えられる. 具体例として は, PVDF に比して圧電効果の大きいフッ化ビニリデ ントリフルオロエチレン共重合体 (P(VDF/TrFE) や PZT を高分子中に分散した有機無機ハイブリッド材料 のアクチュエータ層への適用による制御力向上, UV 硬化型や熱硬化型接着剤等の高硬度接着層形成による ダンピングの影響低減，アクチュエータ層及びセンサ 層の積層数最適化による出力調整などが挙げられる.

図9および図10はセンサ層から得られた出力を示し
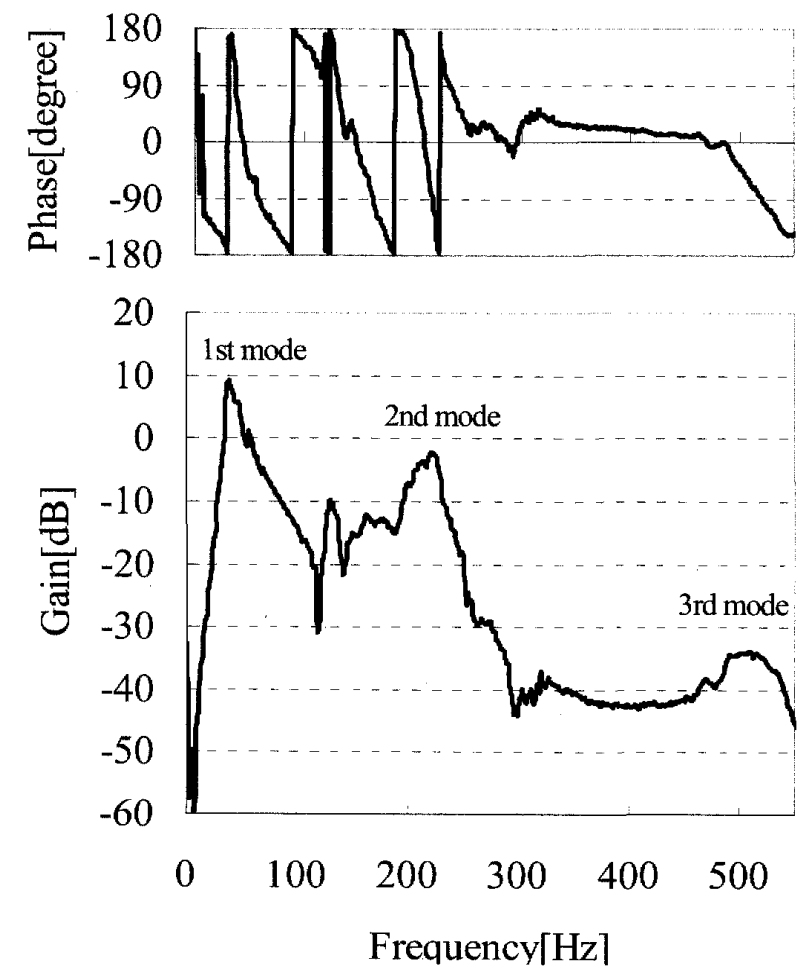

Fig. 7 Frequency characteristics of a modal control film (without control).
ており，図 9 は非制御状態，図 10 は制御状態を示す。 非制御状態では対象とする 1 次モードは対象外の振動 モードに比して $25 \mathrm{~dB}$ 以上の高い出力を得ており，単 独モ一ドセンサとして充分に機能し得る性能であるこ とがわかる. また制御状態では 1 次モードの出力のみ が 20dB 以上抑制されていることがわかる. 図 9 及び 図 10 において, 対象外の振動モードを検出した原因と しては, (1)電極形成時の露光工程におけるフォトマス クの位置ずれに起因した電極形状の誤差，(2)センサフ ィルムとアクチュエータフィルムの貼り合せ位置精度, (3)貼り合せ時の微小な気泡混入及び配線に起因した 面内のフィルム厚み分布が考えられる. (1)及び(2)に関 しては，液晶ディスプレイや半導体製造で用いられて いるようなアライメントマークと光学顕微鏡観察を用 いた露光及び貼り合せ技術を適用することで，さらな る高精度化が期待である. また(3)に関しては, 真空ラ ミネータの利用による気泡除去や露光工程での信号取 り出し用微細配線の同時形成により, フィルム特性の 更なる均質化が期待できる. このように, 先述の材料 面における改良とプロセス面での改良により，モード 制御フィルムとしてさらなる高精度化が期待できる.

以上の結果から, 本論文で提案した分布定数系セン
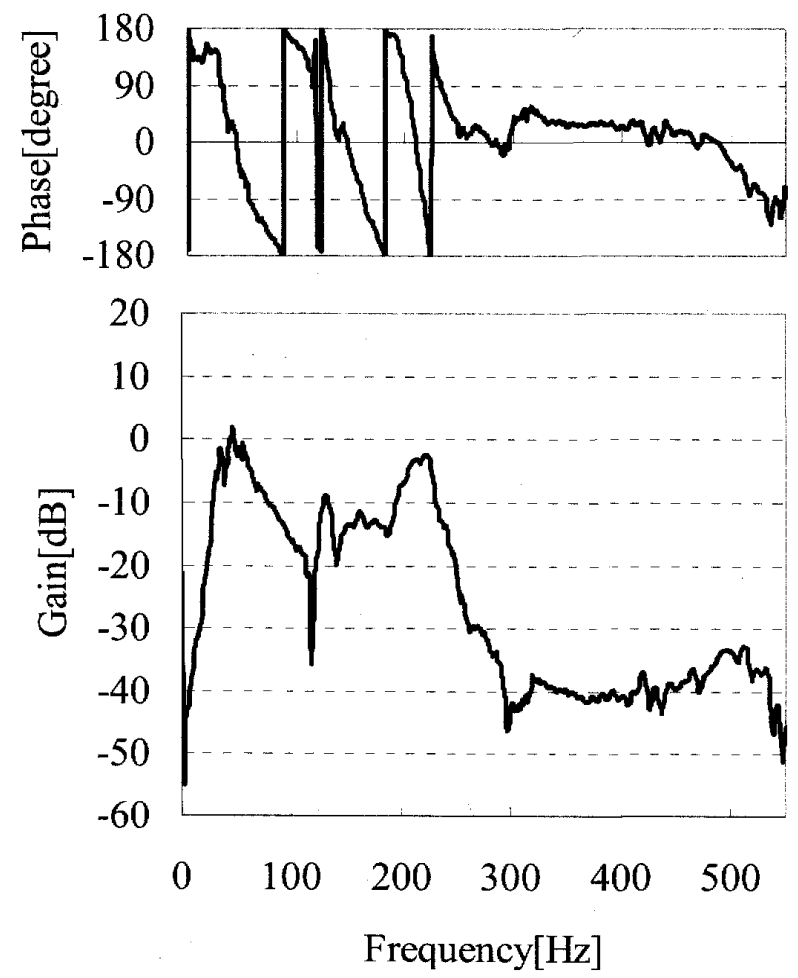

Fig. 8 Frequency characteristics of a modal control film (with control). 


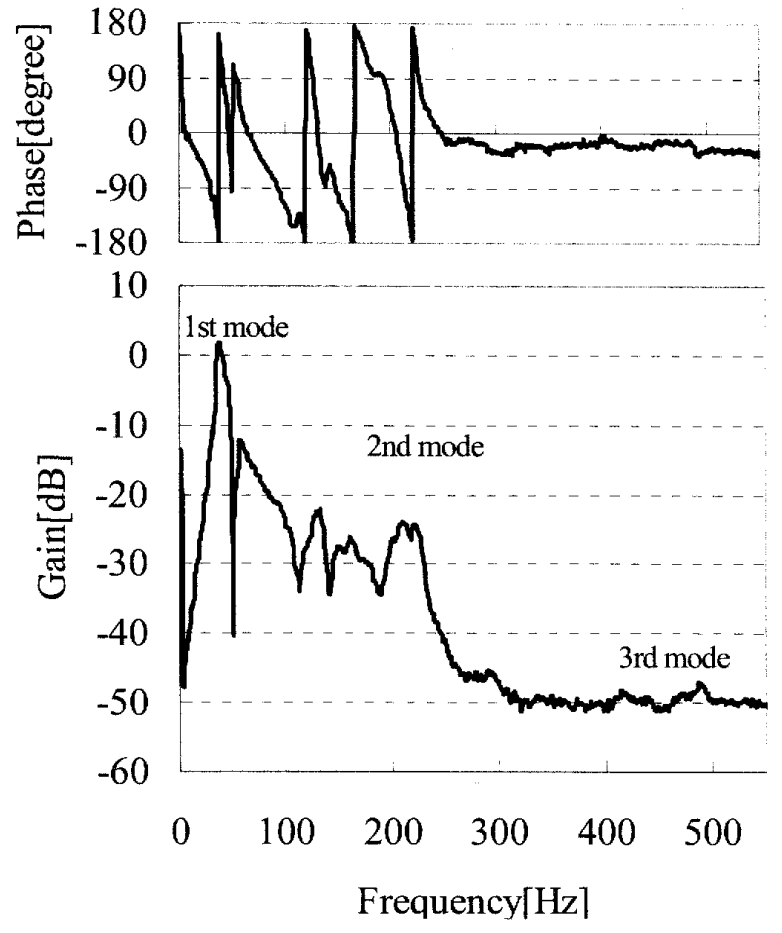

Fig. 9 Amplitude characteristics of the modal sensor layer output signal (without control).

サフィルムとアクチュエータフィルムを積層した構造 体により，フィルム自体がモード制御機能を有する極 薄のスマートフィルムとして機能することを実験によ り確証できたといえる，本論文では制御対象とする振 動モ一ドを 1 個としたが, 異なる振動モードを対象と したセンサ・アクチュエータ層を更に積層することで, 制御対象とする振動モードを増加することも充分に可 能である.これは薄膜フィルム一枚のみで, 狙いとす る周波数帯域内に存在する複数の振動モ一ドを全て制 御できることを意味しており，スピルオーバ問題を克 服する新たなスマートフィルムとして期待できる.

\section{5. 結言}

フィルムの表面改質技術である電極パターニング技術 と積層化技術を融合した分布定数系センサおよびアク チュエータフィルムを基調とするモード制御系を構築 し，実験によりその効果を実証した，本論文はまず， 分布定数系センサおよびアクチュエータで構成される モード制御系の統括より始めた。本構成においては, 制御スピルオーバおよび観測スピルオーバが発生しな

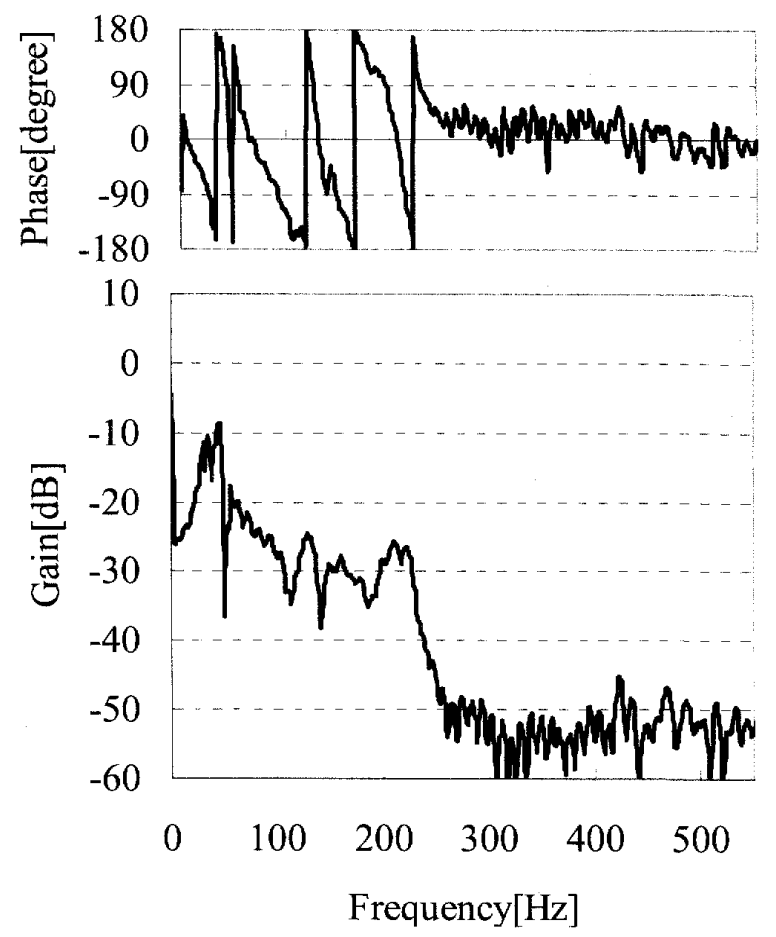

Fig. 10 Amplitude characteristics of the modal sensor layer output signal (with control).

いことを明示した. 続いて電極パターニング手法とラ ミネート法を融合し, 分布定数系センサとアクチュエ 一タフィルムが一体化したスマートフィルムの作製手 法について提案を行つた. さらに一次元平板状構造物 を対象として，本スマートフィルムを用いたモード制 御系を構築し, 実験による制御効果の検証を行った. その結果, 制御対象とする振動モードにおいて $15 \mathrm{~dB}$ の抑制効果を得た. また, 対象とする振動モ一ド以外 には殆ど影響することなく当該モードのみの抑制を達 成した. このことにより，モードフィルタリング機能 やモードアクチュエーティング機能などの単独機能に 続き, 僅か数百 $\mu \mathrm{m}$ 厚のフィルム自体がモ一ド制御機 能を担う高精度のスマートフィルム創生に成功した。 


\section{文献}

(1) Rosen Brock, H. H., Distinctive problems of process control, Chemical Engineering Progress, Vol. 58, No. 9 (1962), pp. 43-50

(2) Gould, L. and Murray-Lasso, M., On the modal control of distributed systems with distributed feedback, IEEE Trans. Autom. Control, Vol. 11, No. 4(1966), pp. 729-737.

(3) Mayne, D. Q. and Murdoch, P., International Journal of Control, Vol. 11, No. 2(1970), pp. 223-227.

(4) Meirovitch, L. and Baruh, H., Control of Self-Adjoint Distributed parameter System, Journal of Guidance, Control and Dynamics, Vol. 5, No. 1(1982), 60-66.

(5) Tanaka, N., Kikushima, Y., Kuroda, M., Modal Control of Planar Structure Using Distributed parameter Sensors, Transactions of the Japan Society of Mechanical Engineers, Series C, Vol. 63, No. 606 (1997), pp. 409-416.

(6) Tanaka, N. and Kobayashi, I., Smart Modal Control of a Simply Supported Flexible Panel Using Smart Actuators, Transactions of the Japan Society of Mechanical Engineers, Series C, Vol. 71, No. 708 (2005), pp. 2512-2519.

(7) Tanaka, N., Kikushima, Y., Kuroda, M., Spatial modal filtering using point sensors, Transactions of the Japan Society of Mechanical Engineers, Series C, Vol. 63, No. 609 (1997), pp. 1559-1567.

(8) Lee, C. K. and Moon, F. C., Modal Sensors Actuators, Trans. ASME. Journal of Applied Mechanics, 57 (1990), pp. 434-441.

(9) Collins, S. A., Miller, D. W., von Flotow, A. H., Distributed Sensors as Spatial Filters in Active Structural Control, Journal of Sound and vibration, Vol. 173, No. 4(1994), pp. 471-501.

(10) Tanaka, N., Kikushima, Y., Kuroda, M., Senba, H., Distributed Parameter Modal Sensors, Transactions of the Japan Society of Mechanical Engineers, Series $C$, Vol. 62, No. 596 (1996), pp. 1418-1425.

(11) Tanaka, N., Kikushima, Y., Kuroda, M., Design Procedure of one dimensional Distributed Parameter smart sensors, Transactions of the Japan Society of Mechanical Engineers, Series C, Vol. 61, No. 590 (1995), pp. 3923-3930.

(12) Kikushima, Y. and Tanaka, N., Active Vibration Control of a Truss Structure Using Modal Sensors, Transactions of the Japan Society of Mechanical Engineers, Series C, Vol. 69, No. 686 (2003), pp. 2999-3006.

(13) Senba, H., Tanaka, N., Kikushima, Y., Kuroda, M., Vibration-Mode Filtering for Flexible Beams Using Optical Fibers, Transactions of the Japan Society of Mechanical Engineers, Series C, Vol. 62, No. 602 (1996), pp. 3929-3937.

(14) Tanaka, N., Snyder, S. D., Hansen, C. H., Distributed Parameter Modal Filtering Using Smart Sensors, $A S M E$, Journal of the Vibration and Sound, Vol. 118, (1996), pp. 630-640.

(15) Tanaka, N., Kobayashi, I., Smart modal control of a simply supported flexible panel using smart actuators, Transactions of the Japan Society of Mechanical Engineers, Series C, Vol. 71, No. 708 (2005), pp. 2461-2468.

(16) Yoneyama, S. and Tanaka, N., Smart Film Sensors Using Electrode Patterning Technique of Film Surface, Transactions of the Japan Society of Mechanical Engineers, Series C, Vol. 75, No. 758
(2009), pp. 2489-2495.

(17) Yoneyama, S. and Tanaka, N., Multi-modal Smart Film Sensors Using Electrode Patterning and Laminating Technique, Transactions of the Japan Society of Mechanical Engineers, Series C, Vol. 75, No. 758 (2009), pp. 2672-2678.

(18) Yoneyama, S. and Tanaka, N., Smart Film Actuators Using Electrode Patterning and Laminating Technique, Transactions of the Japan Society of Mechanical Engineers, Series C, Vol. 75, No. 758 (2009), pp. 2679-2685. 